\title{
Central bank credibility and forecasting
}

\author{
MICHAEL L. MARLOW \\ Department of Economics, California Polytechnic State University, San Luis Obispo, \\ CA 93407, USA
}

\section{INTRODUCTION}

The relation between money and the economy during the 1980 s has caused many economists to reassess their position on the desirability of using the money supply to guide monetary policy. Primary issues include the measurement of money and variability in the lags in monetary policy. The importance that many economists and policy-makers place on money growth has diminished as many believe that the lagged effects of money on real output and prices have either increased, become less reliable or vanished. As the experience of the 1980s continues to confound the profession, it is commonplace for economists to suggest that more data are needed before we can understand how money is now affecting the economy.

This paper examines the hypothesis that the predictive ability of money is affected by central bank policy. It is hypothesized that the ability to forecast the short-run and long-run lagged influences of money on real output and prices is affected by central bank policy. This hypothesis follows the 'Lucas (1976) critique' which argues that model predictability is influenced by policy regimes. In our case, predictions of real output and inflation based on a model whose coefficients are estimated from one policy regime may be expected to deteriorate rapidly when policy regimes change. An implication of this hypothesis is that when policy regimes change the conventional dictum that "more data are better than less data' is not necessarily true when one forecasts economic variables that are influenced by those public policies.

As a test of this hypothesis, this paper examines the predictive ability of money in the 1980s. It is argued that 1980 s monetary policy is more similar to the 1960 s than that of the 1970s and, therefore, real output and inflation in the 1980s should be better predicted from a model based on the experience of the 1960s versus the 1970s. Because support for this hypothesis is found, it is concluded that the 1980s relation between money and the economy is better understood when recent data (1970s) are excluded in favour of past data (1960s) that more closely approximate central bank behaviour in the prediction interval. The paper concludes with several policy implications.

\section{LITERATURE REVIEW}

The work of Friedman and Schwartz (1963) led to many empirical studies of the money-economy relation. While there exists widespread agreement on the long-run effects of money on prices, the determinants of the lags in monetary policy remain an unresolved issue. The fact that no theory exists which explains variability in the lag is a major issue regarding the desirability of using a money-rule for monetary policy. While the early work of Friedman and Schwartz, which used the NBER methodology of determining turningpoints in the data, noted time-variations in the lag, their overall conclusion was that the lag was unpredictable. ${ }^{1}$ Cargill and Meyer (1978) concluded that the lag is influenced by the stage of the business cycle at which the monetary policy stance is changed. Testing for the significance of the stage of the business cycle and stance of monetary policy, Tanner (1979) argued that, while the lag varies systematically with the stance of monetary policy, the lag is not predictable over the business cycle.

Studying 1955-79, Carlson (1980) estimated that the lag from money to prices shortened during the 1970s to approximately 3 years, from 5 years. Carlson suggested that greater predictability of money growth in the 1970s may explain lag-differences since where money growth is more dominated by its systematic component, markets will have a relatively easier time forming reliable inflationary expectations. Since Lucas (1972) and Sargent and Wallace (1973) conclude that the ability of monetary policy to affect real output is related to expectations concerning the central banks's operating policy, monetary policy lags are related to many factors that may change over time. This research suggests that monetary policy lags are variable since the speed with which a change in money growth, for example, affects prices is predictable to the extent that one successfully predicts, among other factors, central bank operating policy.

\footnotetext{
${ }^{1}$ Subsequent papers using the NBER methodology are Mayer (1967), Poole (1975) and Warburton (1971).
} 
Meltzer (1987, p. 11), in a comprehensive assessment of forecasting models, attributes much of their error to 'mainly random variation caused by myriad unanticipated real shocks, changes in expectations, foreign influences, and actual, perceived or anticipated changes in government policy action'. Meltzer argues that, on average, real output predictions are so unreliable that 'it is generally not possible to distinguish consistently between a boom and a recession either in the current quarter or a year in advance'. This observation may suggest that random monetary policy is a major reason for the size and consistency of forecasting errors.

Cukierman and Meltzer (1986) introduce the term 'credibility', which is associated with the speed with which markets recognize that a change in central bank behaviour has occurred. While the random element in policy cannot be known by the market, Cukierman and Meltzer argue that the public monitors money growth in an attempt to detect changes in policy. They suggest the variance of money growth as one measure of credibility. Credibility could also be defined in terms of the systematic versus random components in money growth. The more systematic the policy, the more credible the policy since it is easier for the public to know when policy changes occur.

This literature survey suggests that the ability to predict the lagged influences of money on real output and inflation is related to central bank behaviour. While early research emphasizes lag-unpredictability, rational expectations emphasize that the speed by which money growth is converted into price changes depends on the ability of markets to anticipate central bank policy. The credibility literature emphasizes that markets monitor money growth for changes in central bank policy. These literatures suggest that central bank behaviour and public monitoring of that behaviour affect how money is transmitted through the economy.

\section{HYPOTHESIS}

Because it is argued that central bank policy in the 1980s is more similar to that experienced in the 1960s than the 1970s, it is hypothesized that the ability of money to predict the 1980 s economy is better understood using a model based on the 1960 s versus the 1970 s. Due to data constraints, the most complete data interval begins in 1960 .

Though credibility is difficult to define, it appears to be related to predictability. Several methods may provide information on central bank credibility over 1960-89Q2. One way examines money growth variability. Carlson (1980) compared the standard deviations of money growth and argued that greater money predictability yields greater predictability of how money affects the economy. Examining the hypotheses of Friedman (1983) and Mascaro and Meltzer (1983) that money volatility in the 1980s caused a velocity decline, Hall and Noble (1987), Brocato and Smith (1989) and Mehra (1989) measure money variability as 8 -quarter moving standard deviations of money growth, i.e. where the standard deviations of money growth for the current period is measured over the previous eight quarters.

Table 1 displays summary statistics on monetary aggregates for selected time-periods. Means and standard deviations suggest that M1A and M1 experienced relatively small variation in growth rates during the 1970 s. $^{2}$ Based on crude 'signal-noise' measures (means/standard deviations) for M1A and M1, the 1970s appear to have been characterized by relatively high credibility as opposed to the 1960s and 1980s. Based on the same definition of credibility, central bank policy regarding $\mathbf{M} 2$ displays falling predictability over this period. ${ }^{3}$

Another approach examines the anticipated/unanticipated mix of money growth in order to characterize the degree to which policy periods are predictable. Cagan and Gandolfi (1969) argue that because it is difficult to measure unanticipated components, it is adequate to measure them as changes in money growth rates. Barro and Rush's (1980) method of regressing money growth on lagged values of money growth and other relevant variables is another popular method to measure anticipated money growth.

The Barro and Rush approach estimates a central bank 'reaction function'. While this approach is useful, a serious complication arises from the 'Lucas critique' observation that when causal policy-related explanatory factors undergo

Table 1. Summary statistics of money growth (quarterly growth rates)

\begin{tabular}{llll}
\hline Time & Mean & Std. Dev. & Mean/Std. Dev. \\
\hline M1A & & & \\
1960-89Q2 & 4.3 & 4.0 & 1.1 \\
1960-69 & 3.7 & 2.5 & 1.5 \\
1970-79 & 5.9 & 2.1 & 2.8 \\
1980-89Q2 & 3.2 & 5.9 & 0.5 \\
M1 & & & \\
1960-89Q2 & 5.8 & 4.1 & 1.4 \\
1960-69 & 3.7 & 2.5 & 1.5 \\
1970-79 & 6.4 & 2.2 & 2.9 \\
1980-89Q2 & 7.3 & 5.7 & 1.3 \\
M2 & & & \\
$1960-89$ Q2 & 7.9 & 3.2 & 25 \\
1960-69 & 6.8 & 2.0 & 3.4 \\
1970-79 & 9.3 & 3.3 & 2.8 \\
1980-89Q2 & 7.6 & 3.5 & 2.2 \\
\hline
\end{tabular}

${ }^{2} \mathrm{MIA}=\mathrm{M} 1$ - other checkable deposits (OCDs). See Darby et al. (1989) for a discussion of M1A's usefulness for monetary policy. ${ }^{3}$ The findings of Table 1 appear to be supported by the following statistics. Means of 8-quarter moving standard deviations for M1A for the $1960 \mathrm{~s}, 1970 \mathrm{~s}$ and $1980-1989 \mathrm{Q} 2$, respectively, 1.96, 1.78 and 4.36. For M1, the same statistics are: 1.97 , 1.69 and 4.53. For M2, the same statistics are $1.55,2.53$ and 2.67 . 
significant changes, the success associated with past structural relations to predict the future tends to deteriorate with successive predictions. Therefore, our ability to compare successfully the systematic nature of monetary policy over $1960-89$ Q2 requires that we model successfully changes in the money supply process over this time. Because specifications of different reaction functions are necessary for each policy regime and monetary aggregate, this task is beyond the scope of the present paper.

Another approach examines the relation between changes in money growth and changes in nominal bond yields. Interest in the 'announcement' effect may be related to central bank credibility - when market participants feel they have considerable understanding of central bank policy, they may believe they can better interpret changes in money growth. The hypothesis here is that the higher is credibility, the lower should be the response to transitory versus permanent money shocks. That is, relatively larger changes in money growth can be expected to exert relatively little effect on long-term interest rates when market participants expect the central bank to offset the money growth change in the near future. ${ }^{4}$ While a useful approach, implementation of this strategy entails the task of specifying central bank 'reaction functions' in order to discriminate between two different, but related, components of money growth changes: anticipated/unanticipated and transitory/permanent. Urich and Wachtel (1981) and Cornell (1983) are but two examples of studies measuring the effect of money supply 'announcements' on interest rates.

The last approach discussed here compares the predictability of money growth in the 1980 s based on two different models of the money supply process: the 1960s versus the 1970s. Out-of-sample predictions of autoregressive AR(4) models of quarterly M1A, M1 and M2 growth indicate that the root mean square errors (RMSEs) of forecasts over 1980Q1-1989Q2 generally favour the AR(4) model estimated over the 1960s. RMSEs based on the 1960s (1970s) for M1A, M1 and M2 are, respectively, 7.0 (6.2), $5.8(6.0)$ and 3.8 (4.1). Using the Darby et al. (1989) argument that 1983 is an appropriate starting-date for evaluation of the $1980 \mathrm{~s}$, the same statistics are $3.1(3.6), 4.0(4.9)$ and $3.6(4.0){ }^{5}$

Based on the above evidence, it is hypothesized that the influence of money on the economy during the 1980 s is more similar to that experienced in the 1960 s versus the 1970 s. To the extent that differences in money growth variability and predictability reflect differences in credibility, it is argued that the 1970 s was a period of relatively high central bank credibility where markets perceived central bank policy as relatively dominated by systematic behaviour. In contrast, the 1960 s and 1980s appear to be periods characterized by relatively low credibility whereby markets have less confidence about determining the permanence of current money growth rates and undergo relatively frequent changes in perceptions of central bank policy.

\section{METHODOLOGY}

For the United States, the St Louis-reduced form model is used to estimate two equations: one based on the 1960s and one based on the 1970s. From these two estimations, out-ofsample forecasts of real output and inflation are conducted for two periods: 1980Q1-1989Q2 and 1983Q1-1989Q2. One advantage to using the $\mathrm{St}$ Louis equation is that its 'pros and cons' are well known and need not be addressed here. The question of which monetary aggregate is 'best' in prediction is not addressed here.

The St Louis equation is disaggregated from its original nominal GNP form into its inflation (price deflator) and real GNP components - a disaggregation which may suggest if differences over forecasting intervals can be attributed to either component of nominal GNP. Distributed lags of money (M1A, M1 and M2) and federal expenditures (national income accounts basis) are explanatory variables. All data are transformed into (400 times) log first-differences. ${ }^{6}$

There exists an important literature on lag length selection. ${ }^{7}$ However, in this forecasting exercise, it does not appear appropriate to estimate separately 'optimal' lag lengths for the 1960s and the 1970s and then compare their out-of-sample predictive abilities. Because such a strategy assumes that 'optimal' lag lengths of the 1960s and the 1970s remain in the 1980s, placement of this assumption on the data may arbitrarily affect the results of the forecasting exercise. In an application of the popular Pagano and Hartley (1981) lag length criteria to the St Louis model, Batten and Thornton (1983) report that the technique is relatively insensitive to the choice of lag length. Moreover, one of the conclusions of Thornton and Batten (1985, p. 176) is that 'it appears that the safest approach is to perform an extensive search of the lag space'.

For both monetary and fiscal variables, three alternative lag lengths $(3,4$ and 5 years) are assumed to represent an extensive search of the lag space and to reduce the likelihood that the results of the forecasting exercise are dependent on

\footnotetext{
${ }^{4}$ Lack of interest in money growth may suggest considerable lack of knowledge and be indicative of the 1980 s where market participants may believe that money growth is dominated by its random component and/or market participants may understand policy but realise that this policy downplays or ignores money growth

${ }^{5}$ Starting with 1983 is argued to the transitory influences of early 1980 s financial deregulation on the monetary aggregates.

${ }^{6}$ All data are obtained from Citibase data tapes. While some correctly argue that other variables are important, the usual control variables are excluded here since they often involve use of dummy variables that will not normally exhibit non-zero values over all the intervals being examined.

${ }^{7}$ For example, see Batten and Thornton (1983).
} 
arbitrarily chosen lag lengths. ${ }^{8} \mathrm{~A}$ second-degree polynomial is used for both monetary and fiscal variables and follows Darby et al. (1989) which finds this a reasonable approximation over this time-period.

\section{ESTIMATION}

Table 2 displays estimations of the real GNP equations for each interval. Because the results do not appear to differ

Table 2. Estimations of real GNP equation

\begin{tabular}{|c|c|c|c|c|c|c|}
\hline \multirow[b]{2}{*}{ Est. period ${ }^{a}$} & \multicolumn{2}{|l|}{ M1A } & \multicolumn{2}{|l|}{ M1 } & \multicolumn{2}{|l|}{ M2 } \\
\hline & $1960 \mathrm{~s}$ & $1970 \mathrm{~s}$ & $1960 \mathrm{~s}$ & $1970 \mathrm{~s}$ & $1960 \mathrm{~s}$ & $1970 \mathrm{~s}$ \\
\hline $\begin{array}{l}\text { Constant } \\
t \text {-stat }\end{array}$ & $\begin{array}{l}5.42 \\
4.35\end{array}$ & $\begin{array}{r}-2.43 \\
0.38\end{array}$ & $\begin{array}{l}5.42 \\
4.35\end{array}$ & $\begin{array}{l}1.65 \\
0.30\end{array}$ & $\begin{array}{r}-1.21 \\
0.44\end{array}$ & $\begin{array}{r}-4.57 \\
1.12\end{array}$ \\
\hline $\begin{array}{l}\text { Expend } \\
t \text {-stat } \\
F \text {-stat }\end{array}$ & $\begin{array}{r}-0.23 \\
1.35 \\
1.73\end{array}$ & $\begin{array}{l}0.27 \\
0.90 \\
0.42\end{array}$ & $\begin{array}{r}-0.23 \\
1.35 \\
1.77\end{array}$ & $\begin{array}{l}0.17 \\
0.59 \\
0.20\end{array}$ & $\begin{array}{r}-0.21 \\
1.50 \\
2.15\end{array}$ & $\begin{array}{r}-0.26 \\
0.84 \\
0.52\end{array}$ \\
\hline $\begin{array}{l}\text { Money } \\
t \text {-stat } \\
F \text {-stat }\end{array}$ & $\begin{array}{r}-0.01 \\
0.04 \\
5.90\end{array}$ & $\begin{array}{l}0.43 \\
0.58 \\
9.87\end{array}$ & $\begin{array}{r}-0.01 \\
0.04 \\
5.90\end{array}$ & $\begin{array}{r}-0.16 \\
0.28 \\
9.26\end{array}$ & $\begin{array}{l}0.96 \\
3.10 \\
6.14\end{array}$ & $\begin{array}{l}1.08 \\
3.27 \\
7.04\end{array}$ \\
\hline $\begin{array}{l}\bar{R}^{2} \\
\text { DW } \\
\text { F } \\
\text { SEE } \\
n \\
\text { SSR }\end{array}$ & $\begin{array}{c}0.20 \\
2.06 \\
3.54 \\
2.74 \\
40 \\
262.48\end{array}$ & $\begin{array}{c}0.31 \\
2.35 \\
5.31 \\
3.74 \\
40 \\
489.16\end{array}$ & $\begin{array}{c}0.21 \\
2.06 \\
3.55 \\
2.74 \\
40 \\
261.95\end{array}$ & $\begin{array}{c}0.29 \\
2.27 \\
5.00 \\
3.78 \\
40 \\
500.29\end{array}$ & $\begin{array}{c}0.21 \\
2.11 \\
3.63 \\
2.73 \\
40 \\
260.14\end{array}$ & $\begin{array}{c}0.23 \\
2.16 \\
3.86 \\
3.95 \\
40 \\
545.50\end{array}$ \\
\hline
\end{tabular}

${ }^{a}$ Estimation interval of 1960Q1-1969Q4 or 1970Q1-1979Q4.

bSum of lag coefficients for polynomial distributed lags of 12 quarters, second degree and far-end constrained.

$t$-statistics below coefficients, followed by $F$-statistics for the null hypothesis that all lagged coefficients are statistically different from zero.

Table 3. Estimations of inflation equation

\begin{tabular}{|c|c|c|c|c|c|c|}
\hline \multirow[b]{2}{*}{ Est. period ${ }^{a}$} & \multicolumn{2}{|l|}{ M1A } & \multicolumn{2}{|l|}{ M1 } & \multicolumn{2}{|l|}{$\mathbf{M} 2$} \\
\hline & $1960 \mathrm{~s}$ & $1970 \mathrm{~s}$ & $1960 \mathrm{~s}$ & $1970 \mathrm{~s}$ & $1960 \mathrm{~s}$ & $1970 \mathrm{~s}$ \\
\hline $\begin{array}{l}\text { Constant } \\
t \text {-stat }\end{array}$ & $\begin{array}{r}-0.51 \\
0.76\end{array}$ & $\begin{array}{r}-2.59 \\
0.84\end{array}$ & $\begin{array}{r}-0.52 \\
0.77\end{array}$ & $\begin{array}{r}-2.06 \\
0.79\end{array}$ & $\begin{array}{r}-1.40 \\
0.82\end{array}$ & $\begin{array}{l}4.07 \\
2.20\end{array}$ \\
\hline $\begin{array}{l}\text { Expend }^{\mathrm{b}} \\
t \text {-stat } \\
F \text {-stat }\end{array}$ & $\begin{array}{l}0.01 \\
0.78 \\
0.35\end{array}$ & $\begin{array}{l}0.29 \\
2.07 \\
2.12\end{array}$ & $\begin{array}{l}0.01 \\
0.88 \\
0.13\end{array}$ & $\begin{array}{l}0.28 \\
2.00 \\
2.15\end{array}$ & $\begin{array}{r}0.29 \\
29.00 \\
5.37\end{array}$ & $\begin{array}{l}0.33 \\
2.36 \\
3.19\end{array}$ \\
\hline $\begin{array}{l}\text { Money } \\
t \text {-stat } \\
F \text {-stat }\end{array}$ & $\begin{array}{l}0.81 \\
5.78 \\
9.15\end{array}$ & $\begin{array}{l}1.15 \\
3.19 \\
8.39\end{array}$ & $\begin{array}{l}0.80 \\
5.71 \\
8.98\end{array}$ & $\begin{array}{l}1.05 \\
4.04 \\
9.02\end{array}$ & $\begin{array}{l}0.33 \\
1.74 \\
1.53\end{array}$ & $\begin{array}{r}0.01 \\
0.06 \\
8.91\end{array}$ \\
\hline $\begin{array}{l}\bar{R}^{2} \\
\text { DW } \\
\text { F } \\
\text { SEE } \\
n \\
\text { SSR }\end{array}$ & $\begin{array}{l}0.45 \\
2.12 \\
8.84 \\
1.47 \\
40 \\
75.54\end{array}$ & $\begin{array}{c}0.30 \\
1.58 \\
5.24 \\
1.80 \\
40 \\
114.01\end{array}$ & $\begin{array}{l}0.44 \\
2.11 \\
8.77 \\
1.47 \\
40 \\
75.87\end{array}$ & $\begin{array}{c}0.32 \\
1.61 \\
5.56 \\
1.78 \\
40 \\
111.50\end{array}$ & $\begin{array}{c}0.22 \\
1.59 \\
3.81 \\
1.74 \\
40 \\
105.76\end{array}$ & $\begin{array}{c}0.32 \\
1.65 \\
5.53 \\
1.79 \\
40 \\
111.76\end{array}$ \\
\hline
\end{tabular}

aEstimation interval of 1960Q1-1969Q4 or 1970Q1-1979Q4.

bSum of lag coefficients for polynomial distributed lags of 12 quarters, second degree and far-end constrained.

t-statistics below coefficients, followed by $F$-statistics for the null hypothesis that all lagged coefficients are statistically different from zero.

${ }^{8}$ In the case of the lagged effect of money on inflation, Carlson's (1980) application of the St Louis model found that the lag pattern shifted from 5 years over 1955 69, to 3 years in the 1960s. Barro (1981) argued for a 3-year lag from inoney to real output. Darby et al. (1989) argued that 3 years is appropriate for the real GNP equation and 4 years for the inflation equation. 
between lag lengths, only those for 3 years are displayed. ${ }^{9}$ Two test statistics are reported for each lagged policy variable: and $F$-test on the null hypothesis that all lag coefficients, as a group, are zero and the $t$-test on the null hypothesis that the sum of the estimated coefficients are zero. The $F$-test suggests whether or not policy variables exert transitory effects on the dependent variable. The $t$-test indicates whether the sum of individual coefficients exerts a permanent effect on the dependent variable.
Government expenditures (Expend) are generally found to exert neither transitory nor permanent effects on real GNP. The one exception is the positive and statistically significant (95\% confidence) coefficient in the 1960 s estimation of the M2 equation. Over both estimation intervals, permanent positive effects from money growth are shown only in the case of M2. However, all money measures indicate transitory effects on real GNP. (Table A.1 displays the distributed lag coefficients associated with the money

Table 4. Summary predictive statistics

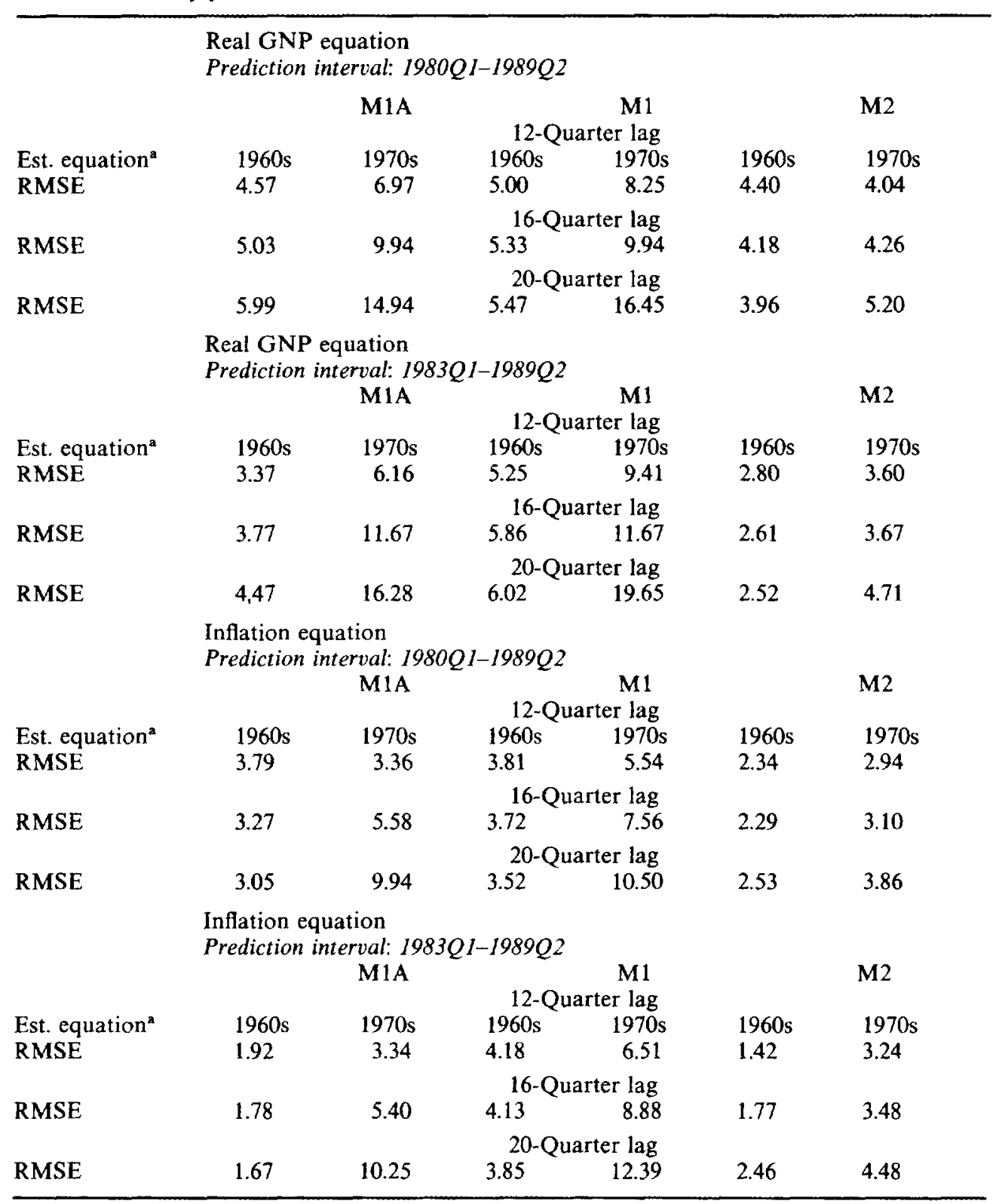

${ }^{2}$ Estimation period of 1960Q1-1969Q4 or 1970Q1-1979Q4.

\footnotetext{
${ }^{9}$ The major difference between lag lengths is for the 5-year lag where fiscal policy exerts transitory influences on real GNP in the equations using M1A and M1.

${ }^{10} \mathrm{M} 1 \mathrm{~A}$ and $\mathrm{M} 1$ growth show permanent negative effects on real GNP in estimations of the 1970 period using 5-year lags.

${ }^{11} \mathrm{M} 2$ growth exerts a positive permanent effect on inflation when longer lags are considered.
} 
variables of Table 2.) For M1A and M1, changes in money growth exert initial positive influences on real GNP, followed by negative influences. On net, however, the influences are not permanent. ${ }^{10}$ Positive lagged influences last a few additional quarters in the M2 equation.

Table 3 displays estimations of the inflation equation. Only for M2, and over both estimation intervals, do government expenditures exert positive permanent influences on inflation. Except for M2, where there exists a permanent negative effect, money growth exerts positive permanent influences on inflation. ${ }^{11}$ (Table A.2 displays distributed lag coefficients associated with the money variables of Table 3.)

\section{PREDICTION}

Table 4 displays out-of-sample predictive statistics for real GNP and inflation based on the two estimation periods. Because comparisons based on mean average error criteria yield identical results, only RMSEs are displayed. Comparisons are made between two predictive intervals: 26 quarters 1983Q1-1989Q2 and 38 quarters 1980Q1-1989Q2.

For real GNP, RMSEs associated with M1A and M1 uniformly favour the 1960s model. For example, in the case of predictions based on $\mathrm{M} 1$ and for the longest predictive interval, the differences in RMSE are 3.25 (12 quarter), 4.61 (16 quarter) and 11.0 (20 quarter). The fact that predictive superiority increases with lag length and that the lowest RMSEs correspond to the shortest lag length may simply suggest that one should use a relatively short lag structure for predicting real GNP. With one exception (12-quarter lag over the 1980-89Q2), predictions based on M2 generally favour the 1960s model. However, less significant differences suggest greater relative stability of the M2 real GNP relation.

With one exception (using M1A to predict inflation over 1980Q1-1987Q4 with a 12-quarter lag), 1980s inflation is best predicted by the 1960s expeience.

\section{CONCLUSION}

Based on a model whose coefficients are estimated from the 1960 s versus 1970 s, the influence of money on the economy in the $1980 \mathrm{~s}$ is closer to the experience of the 1960s. This result is consistent with the hypothesis that since a primary difference between the monetary policy regimes of the $1960 \mathrm{~s}$ and 1970s is one of money predictability, the 1980s influence of money on real output and inflation will more closely resemble that of the $1960 \mathrm{~s}$.

One implication is that, in the context of approximately three decades of data, the 1980s experience may not be so different when one considers the long-term experience. Another implication is that lag variability in monetary policy may stem from changes in central bank credibility. To the extent that a switch to more systematic monetary policy lessens lag variability, it might also lead to greater predictability of real output and inflation. Interestingly, the difficulty in predicting how money is transmitted through the economy carries over to the central bank as well, as long as it does not systematically determine its future behaviour. In this sense, this implication is consistent with the proposal, most notably argued by Milton Friedman $(1948,1959)$, that if a money-rule increases the systematic component of money growth, such a rule may allow a greater ability to forecast economic variables.

A final implication is that, because model prediction over different policy regimes may not yield uniformly reliable forecasts, the conventional dictum that 'more data are better than less data' may not be a useful guide to forecasting economic variables that are influenced by public policies. In other words, predictions based on a model whose coefficients are estimated from another policy regime need not improve with arrival of additional observations. As is shown here, the 1980s money-economy relation is better understood (predicted) when recent data (1970s) are excluded in favour of past data (1960s) which appear to be generated by central bank policies more similar to those in the prediction interval. 


\section{APPENDIX A}

Table A.1. Real GNP equations: distributed Lag coefficients on money

\begin{tabular}{|c|c|c|c|c|c|c|}
\hline \multirow{2}{*}{$\begin{array}{l}\text { Est. period: } \\
\text { Lag }\end{array}$} & \multicolumn{3}{|l|}{$1960 \mathrm{~s}$} & \multicolumn{3}{|l|}{$1970 \mathrm{~s}$} \\
\hline & M1A & M1 & M2 & M1A & M1 & $\mathbf{M} 2$ \\
\hline \multirow[t]{2}{*}{1} & 0.34 & 0.34 & 0.34 & 0.61 & 0.59 & 0.29 \\
\hline & 16.98 & 17.13 & 20.88 & 17.85 & 17.35 & 7.49 \\
\hline \multirow[t]{2}{*}{2} & 0.22 & 0.23 & 0.27 & 0.43 & 0.39 & 0.24 \\
\hline & 8.89 & 8.96 & 16.43 & 10.75 & 21.91 & 6.98 \\
\hline \multirow[t]{2}{*}{3} & 0.12 & 0.12 & 0.20 & 0.26 & 0.21 & 0.19 \\
\hline & 5.16 & 5.23 & 30.29 & 4.74 & 11.29 & 5.66 \\
\hline \multirow[t]{2}{*}{4} & 0.01 & 0.01 & 0.14 & 0.12 & 0.01 & 0.14 \\
\hline & 3.26 & 3.44 & 5.71 & 1.76 & 1.42 & 4.11 \\
\hline \multirow[t]{2}{*}{5} & -0.01 & -0.01 & 0.01 & 0.00 & -0.01 & 0.10 \\
\hline & 0.96 & 0.93 & 2.38 & 0.14 & 0.82 & 2.81 \\
\hline \multirow[t]{2}{*}{6} & -0.01 & -0.01 & 0.01 & -0.01 & -0.14 & 0.01 \\
\hline & 1.92 & 1.91 & 1.00 & 0.86 & 1.87 & 1.84 \\
\hline \multirow[t]{2}{*}{7} & -0.12 & -0.12 & 0.01 & -0.14 & -0.21 & 0.00 \\
\hline & 2.41 & 2.41 & 0.22 & 1.54 & 2.48 & 0.12 \\
\hline \multirow[t]{2}{*}{8} & -0.14 & -0.14 & -0.00 & -0.18 & -0.24 & 0.00 \\
\hline & 2.72 & 2.72 & 0.27 & 2.02 & 2.88 & 0.58 \\
\hline \multirow[t]{2}{*}{9} & -0.14 & -0.14 & -0.00 & -0.19 & -0.25 & 0.01 \\
\hline & 2.93 & 2.93 & 0.62 & 2.38 & 3.16 & 0.17 \\
\hline \multirow[t]{2}{*}{10} & -0.13 & -0.13 & -0.01 & -0.18 & -0.23 & -0.00 \\
\hline & 3.09 & 3.09 & 0.88 & 2.66 & 3.37 & 0.15 \\
\hline \multirow[t]{2}{*}{11} & -0.10 & -0.10 & -0.00 & -0.15 & -0.18 & -0.00 \\
\hline & 3.21 & 3.21 & 1.08 & 2.88 & 3.53 & 0.41 \\
\hline \multirow[t]{2}{*}{12} & -0.01 & -0.01 & -0.00 & -0.01 & -0.10 & -0.00 \\
\hline & 3.30 & 3.31 & 1.24 & 3.07 & 3.67 & 0.62 \\
\hline
\end{tabular}

Note: absolute $t$-statistic below coefficient.

Table A.2. Inflation equations: distributed Lag coefficients on money

\begin{tabular}{|c|c|c|c|c|c|c|}
\hline \multirow{2}{*}{$\begin{array}{l}\text { Est. period: } \\
\text { Lag }\end{array}$} & \multicolumn{3}{|l|}{$1960 \mathrm{~s}$} & \multicolumn{3}{|l|}{$1970 \mathrm{~s}$} \\
\hline & $\mathbf{M} 1 \mathrm{~A}$ & M1 & $\mathrm{M} 2$ & M1A & M1 & M2 \\
\hline \multirow[t]{2}{*}{1} & 0.11 & 0.11 & -0.01 & -0.01 & -0.11 & -0.13 \\
\hline & 10.32 & 10.19 & 3.75 & 5.24 & 6.84 & 7.15 \\
\hline \multirow[t]{2}{*}{2} & 0.10 & 0.10 & -0.00 & -0.00 & -0.00 & -0.01 \\
\hline & 7.78 & 7.69 & 1.34 & 0.73 & 3.95 & 5.59 \\
\hline \multirow[t]{2}{*}{3} & 0.01 & 0.01 & 0.00 & 0.00 & 0.00 & -0.00 \\
\hline & 7.74 & 7.65 & 1.85 & 1.76 & 3.57 & 3.38 \\
\hline \multirow[t]{2}{*}{4} & 0.01 & 0.01 & 0.00 & 0.01 & 0.01 & -0.00 \\
\hline & 14.78 & 14.94 & 1.64 & 2.82 & 3.85 & 1.31 \\
\hline \multirow[t]{2}{*}{5} & 0.01 & 0.01 & 0.00 & 0.13 & 0.12 & 0.00 \\
\hline & 4.78 & 4.77 & 1.67 & 3.36 & 4.04 & 0.23 \\
\hline \multirow[t]{2}{*}{6} & 0.01 & 0.01 & 0.01 & 0.16 & 0.15 & 0.00 \\
\hline & 3.19 & 3.19 & 1.71 & 3.68 & 4.15 & 1.30 \\
\hline \multirow[t]{2}{*}{7} & 0.01 & 0.01 & 0.01 & 0.17 & 0.17 & 0.00 \\
\hline & 2.46 & 2.46 & 1.73 & 3.89 & 4.22 & 2.06 \\
\hline \multirow[t]{2}{*}{8} & 0.01 & 0.01 & 0.01 & 0.17 & 0.17 & 0.00 \\
\hline & 2.03 & 2.04 & 1.75 & 4.04 & 4.26 & 2.60 \\
\hline \multirow[t]{2}{*}{9} & 0.01 & 0.01 & 0.01 & 0.16 & 0.16 & 0.01 \\
\hline & 1.75 & 1.75 & 1.77 & 4.15 & 4.30 & 3.01 \\
\hline \multirow[t]{2}{*}{10} & 0.01 & 0.01 & 0.00 & 0.14 & 0.14 & 0.00 \\
\hline & 1.54 & 1.55 & 1.78 & 4.23 & 4.32 & 3.32 \\
\hline \multirow[t]{2}{*}{11} & 0.02 & 0.00 & 0.00 & 0.10 & 0.10 & 0.00 \\
\hline & 1.39 & 1.40 & 1.79 & 4.29 & 4.34 & 3.56 \\
\hline \multirow[t]{2}{*}{12} & 0.00 & 0.00 & 0.00 & 0.01 & 0.01 & 0.02 \\
\hline & 1.27 & 1.28 & 1.80 & 4.35 & 4.36 & 3.76 \\
\hline
\end{tabular}

Note: absolute $t$-statistic below coefficient. 


\section{ACKNOWLEDGEMENT}

The author is grateful to an anonymous referee for valuable comments.

\section{REFERENCES}

Barro, R. J. (1981) Unanticipated money growth and economic activity in the United States, in Money, Expectations and Business Cycles, Academic Press, New York.

Barro, R. J. and Rush, M. (1980) Unanticipated money and economic activity, in Rational Expectations and Economic Policy, Fisher, S. (ed.), University of Chicago Press, Chicago, IIl.

Batten, D. and Thornton, D. L. (1983) Polynomial distributed lags and the estimation of the St Louis equation, Federal Reserve Bank of St Louis Review, 65, 13-25.

Brocato, J. and Smith, K. L. (1989) Velocity and the variability of money growth: evidence from the Granger-Causality Tests, Journal of Money, Credit and Banking, 21, 258-61.

Cagan, P. and Gandolfi, A. (1969) The lag in monetary policy as implied by the time pattern of monetary effects on interest rates, American Economic Review, 59, 277-84.

Cargill, T. F. and Meyer, R. A. (1978) The time varying response of income to changes in monetary and fiscal policy, Review of Economics and Statistics, 60, 1-17.

Carlson, K. M. (1980) The lag from money to prices, Federal Reserve Bank of St Louis Review, 62, 3-10.

Cornell, B. (1983) The money supply announcements puzzle, American Economic Review, 73, 644-57.

Cukierman, A. and Meltzer, A. H. (1986) A theory of ambiguity, credibility and inflation under discretion and asymmetric information, Econometrica, 54, 1099-128.

Darby, M. R., Mascaro, A. R. and Marlow, M. L. (1989) The empirical reliability of monetary aggregates as indicators: 1983-87, Economic Inquiry, 27, 555-86.

Friedman, M. (1948) A monetary and fiscal framework for economic stability, American Economic Review, 38, 245-64

Friedman, M. (1959) A program for monetary stability, Fordham University Press, New York.
Friedman, M. (1983) Lessons from the 1979-82 monetary policy experiment, Papers and Proceedings in American Economic Review, 74, 397-400.

Friedman, M. and Schwartz, A. J. (1963) A Monetary History of the United States, 1867-1960, Princeton University Press, Princeton, NJ.

Hall, T. E. and Noble, N. R. (1987) Velocity and variability of money growth: evidence from Granger-Causality Tests, Journal of Money, Credit and Banking, 19, 112-16.

Lucas, R. E., Jr. (1972) Expectations and the neutrality of money, Journal of Economic Theory, 4, 103-24.

Lucas, R. E., Jr. (1976) Econometric policy evaluation: a critique, in Carnegie-Rochester Conference Series on Public Policy, Brunner, $\mathrm{K}$. and H. Allan Meltzer (eds.), 1, 19 46.

Mascaro, A. and Meltzer, A. H. (1983) Long and short-term interest rates in a risky world, Journal of Monetary Economics, 12, 485-518.

Mayer, T. (1967) The lag in the effect of monetary policy: some criticisms, Western Economic Journal, 5, 324 42.

Mehra, Y. P. (1989) Velocity and the variability of money growth: evidence from Granger-causality tests, Journal of Money, Credit and Banking, 21, 262-66.

Meltzer, A. H. (1987) Limits of short-run stabilization policy, Economic Inquiry, 25, 1-14.

Pagano, M. and Hartley, M. J. (1981) On fitting distributed lag models subject to polynomial restrictions, Journal of Econometrics, 171-98.

Poole, W. (1975) The relationship of monetary deceleration to business cycle peaks: another look at the evidence, Journal of Finance, 30, 697-712.

Sargent, T. J. and Wallace, N. (1973) Rational expectations and the theory of economic policy, Journal of Monetary Economics, 2 , 169-83.

Tanner, J. E. (1979) Are the lags in the effects of monetary policy variable? Journal of Monetary Economics, 5, 105-21.

Thornton, D. L. and Batten, D. (1985) Lag-length selection and tests of Granger Causality between money and income, Journal of Money, Credit and Banking, 17, 164-78.

Urich, T. and Wachtel, P. (1981) Market response to the weekly money supply announcements in the 1970s, Journal of Finance, 36, 1063-72.

Warburton, C. (1971) Variability of the lag in the effect of monetary policy, 1919-1965, Western Economic Journal, 9, 115-33. 